\title{
Māori Health: Issues Relating to Health Care Services
}

\begin{abstract}
Since the colonisation of Aotearoa by the British, Māori have experienced health disparities in comparison to non-Māori. While there have been numerous policies and initiatives to improve the diaspora, this is forecasted to continue for the Māori population. The source of this health disparity is complex, being embedded in historic and contemporary inequities. However, one prominent issue which continues to be reported, is the less than adequate health treatment received by Māori in comparison to those of non-Māori or nonPacific origin. According to the Ministry of Health, this is adversely contributing to Māori health inequalities. This paper discusses the difficulties confronted by Māori when accessing health care services.
\end{abstract}

\section{Introduction}

The barriers faced by Māori in the New Zealand health system have recently been the focus of media attention. One such article which gained national coverage is the report concerning the Manukau maternity services (One News, 2014; Fairfax, 2014). This report found Māori mothers to be "dropping out of the system" because they believed health care workers were judgmental (Counties Manukau Health, 2014). The report further mentioned Māori mothers to be among those at the most risk of receiving inadequate care, and to have a

Phoebe Elers is a $\mathrm{PhD}$ candidate at AUT University in the School of Communication Studies (Health Communication). She has a Master of Health Management degree and has several years of experience working in both the public and private health care environment. 
disproportionally higher rate of miscarriages in the region (Counties Manukau Health, 2014). While the report acknowledged various challenges facing the Manukau maternity services such as staff shortages, it indicated that there are key changes needed to accommodate Māori; including applying a family centred approach for care and reconsidering their current policies for families to provide support (Counties Manukau Health, 2014).

The reported inadequacies for Māori at the Manukau maternity services are not unique. Studies have concluded Māori to receive sub optimal health treatment in comparison to those of non-Māori or non-Pacific origin (Davis et al., 2009; Rumball-Smith, Sarfati, Hider \& Blakely, 2013; Penney, Barnes \& McCreanor 2011; Crengle, Lay-Yee, Davis, \& Pearson, 2005). For instance, a national study of New Zealand general health practices found that Māori who were diagnosed with chronic obstructive pulmonary disease are more than $8 \%$ less likely to be given a prescription compared to non-Māori by general practitioners (Crengle et al., 2005). Another study which retrospectively evaluated prescriptions dispensed in 2006 and 2007 found Māori disparities in key areas including medicines for cardiovascular disease, infectious diseases, diabetes and respiratory conditions (Pharmaceutical Management Agency, 2013). Research has also established stigmatisation of Māori patients, where they are more likely to experience discrimination in a health care setting (Harris et al., 2006) and are often incorrectly regarded as non-compliant in relation to their health (Penney et al., 2011).

This evidence is a strong indicator that the health system is failing Māori. In a recent news article, former Taranaki District Health Board member Colleen Tuuta criticised the system's failings for Māori when she stated: "Something is not working. This model is not working. We can build new hospitals but not make people well" (Fairfax, 2013, para. 2). Not surprisingly, many studies have uncovered clear obstacles confronted by Māori when accessing health services (Walker, 
Signal, Russell, Smiler \& Tuhiwai-Ruru, 2008; Jansen, Bacal \& Crengle, 2009; Ministry of Health, 2009; Wilson \& Barton, 2012). In reviewing the literature on this subject, two clear themes have emerged: the marginalisation of Māori within health care services and the conflict between the Māori paradigm and the western model of health care.

\section{Marginalisation of Māori}

A review of the literature indicates that Māori experience marginalisation within New Zealand health services (Williams et al., 2003; Wilson \& Barton, 2012). Māori have reported that the health care environment is catered predominantly towards the dominant group, and that it is not appropriate, or culturally safe (Williams et al., 2003; Wilson \& Barton, 2012). This has resulted in Māori being reluctant to ask questions (Te Karu, Bryant \& Elley, 2013), and not to complain even when observing a substandard of care (Wilson \& Barton, 2012; Jansen et al., 2009). Consequently, Māori feel ill-informed and powerless as a result of their treatment from within the health sector (Wilson \& Barton, 2012).

One of the reported causes of this marginalisation, is staff insensitivity; being described as judgmental (Counties Manukau Health, 2014; Ministry of Health, 2009), rude and disrespectful as well as having poor communication (Jansen et al., 2009). Requests for Māori staff often cannot be met by health care organisations and at times Māori do not consider Pākehā as appropriate service providers (Jansen et al., 2009). This is unfortunate, as research has shown that having a health care practitioner who is understanding of the patient's cultural beliefs improves the likelihood of enhanced health outcomes (Penn, Kar, Kramer, Skinner \& Zambrana, 1995). This is particularly the case amongst Māori, as Māori have reported 'whakamā' ('shyness' or 'embarrassed') as a potential barrier to using health services or from fully disclosing their health issues (Cram, Smith \& Johnstone, 2003). For instance 
research have found Māori patients to be less likely to talk about symptoms of depression with their clinician (Thomas, Arlidge, Arroll \& Elder, 2010).

Another source of disaffection by Māori patients, is medical practices conflicting with their cultural attitudes (Wilson \& Barton, 2012). While there are educational processes in place to ensure practitioners have an understanding of Māori culture (Nursing Council of New Zealand, 2011; The Royal New Zealand College of General Practitioners, 2007), this can be difficult to avoid in the health care environment. For instance, there can be cultural dilemmas for bedridden inpatients who have no other option but to engage in mutually incompatible activities of food consumption and defecation in the same place (Sachdev, 1990).

A clear consequence of health marginalisation is suspicion and even fear of the health system amongst Māori (Bolitho \& Huntington, 2006; Hirini et al., 1999; Sachdev, 1990). According to Cram et al. (2003), Māori experiencing or observing mistreatment in health services has led the wider Māori whānau network to mistrust conventional health practices.

\section{The Conflict with the Western Model of Health Care}

For many Māori, their view on 'health' and 'healing' is conflicting to the philosophies of conventional health services (Jansen et al., 2009; Williams et al., 2003; Wilson \& Barton, 2012). Māori have advocated that health is about people, development and the vision for the future (Ellis \& Collings, 1997). In describing a Māori view of health, Sir Mason Durie (1998) has likened it to the four walls of a strong house, needing to consist of te taha wairua (spiritual wellbeing), te taha hinengaro (mental wellbeing), te taha tinana (physical wellbeing) and te taha whānau (family wellbeing). The concept of te taha wairua (spiritual wellbeing) is 
considered to be an essence within their health being linked to both relationships with the environment and religion beliefs (Cram et al., 2003). Subsequently, when receiving medical treatment in a non-Māori environment, Māori have reported being uncomfortable, anxious and fearing death (Wilson \& Barton, 2012). This is also reflective of Māori frequently caring for their relatives during hospitalisation, despite health workers being available (Wilson \& Barton, 2012).

The Māori concept of health and healing is seen to be misunderstood by most Pākehā practitioners (Cram et al., 2001; Wilson \& Barton, 2012). Most health services conversely practice the biomedical model of care which isolates the physical ailment from the person, neglects its social causes, and disregards the subjective interpretations of health and illness (Nettleton, 2006). This model has also been described as the 'dehumanisation' (Haslam, 2006) and the 'objectification' (Barnard, 2001) of medicine. By individualising the explanation of illness (White, 2009) and framing the unwell as the cause of their own condition (Dorfman \& Wallack, 1993; Hoverd, 2011), it is not considering the Māori view of health and healing (Jones, 2000).

\section{Discussion}

This paper has reviewed literature pertaining to Māori health disparities. The health service provision is based upon the Pākehā biomedical model of care which does not meet their needs (Cram et al., 2001; Wilson \& Barton, 2012). It appears that Pākehā ideologies, which individualises and biologises the explanation of illness (White, 2009), conflict with Māori perceptions that encompass a broader concept of health (Durie, 1998) including te taha wairua (spiritual wellbeing), te taha hinengaro (mental wellbeing), te taha tinana (physical wellbeing) and te taha whānau (family wellbeing). Ultimately, the provision of health services often marginalises Māori 
(Williams et al., 2003; Wilson \& Barton, 2012) and adversely contribute the health inequality amongst Māori (Ministry of Health, 2009).

In fairness, attempts to reform and improve services have been initiated. Over the past decade there have been an amplitude of Māori targeted initiatives, such social marketing campaigns, Māori health worker recruitment initiatives and delivering health services in locations away from medical settings (Barwick, 2000). This paper has provided an informative review of some of the issues facing Māori when accessing mainstream health care in New Zealand. 


\section{References}

Arroll, B., Goodyear-Smith, F., \& Lloyd, T. (2002). Depression in patients in an Auckland general practice. New Zealand Medical Journal, 115(1152), 176-179. Retrieved from https://researchspace.auckland.ac.nz/bitstream/handle/2292/4 505/12043999.pdf?sequence $=1$

Barnard, A. (2001). On the relationship between technique and dehumanization. In R.C. Locsin (Ed.), Advancing technology, caring, and nursing (pp. 96-105). Westport, CT: Auburn House

Barwick, H. (2000). Improving access to primary care for Māori and Pacific peoples. Retrieved from http://www.moh.govt.nz/notebook/nbbooks.nsf/0/0ff9b7c2186f 2628cc2574b2000220cf/\$FILE/HFAimprovingaccess.pdf

Barton, P. (2008). 'A kind of ritual Pakeha tikanga' - Maori experiences of hospitalisation: $A$ case study. Retrieved from http://muir.massey.ac.nz/bitstream/handle/10179/1104/02who le.pdf?sequence $=1$

Bolitho, S., \& Huntington, A. (2006). Experiences of Maori families accessing healthcare for their unwell children: A pilot study. Nursing Praxis in New Zealand, 22(1), 23-32.

Counties Manukau Health (2014). Improving maternity care in Counties Manukau. Retrieved from http://www.countiesmanukau.health.nz/News_Publications/Rep orts/maternitycarereview/Maternity\%20review\%20Media\%20relea se $\% 20$ doc $\% 20$ embargoed.doc

Cram, F., Smith, L., \& Johnstone, W. (2003). Mapping the themes of Maori talk about health. The New Zealand Medical Journal, 116(1170).

Retrieved

from http://journal.nzma.org.nz/journal/116-1170/357/content.pdf

Crengle, S., Lay-Yee, R., Davis, P., \& Pearson, J. (2005). A comparison of Mãori and non-Māori patient visits to doctors: The national primary medical care survey 2001/02 report 6. Retrieved from http://www.moh.govt.nz/notebook/nbbooks.nsf/0/d222772d6d0 1d0facc25748c007d64d8/\$FILE/NatMedCaReport6Dec2005.pdf

Davis, P., Lay-Yee, R., Sporle, A., Dyall, L., Briant, R., Brunt, D., \& Scott, A. (2009). Quality of hospital care for Māori patients in New Zealand: A retrospective cross-sectional assessment. Retrieved from http://www.nzssds.org.nz/book/export/html/69 
Durie M. (1998). Whaiora: Maori health development. 2nd edition. Auckland: Oxford University Press

Ellis, P., \& Collings, S. (1997). Mental health in New Zealand from a public health perspective. Retrieved from http://www.moh.govt.nz/moh.nsf/Files/chap3/\$file/chap3.pdf

Fairfax (2013, December 2). Retiring health members say Maori neglected. Taranaki Daily News. Retrieved from http:/ / www.stuff.co.nz/taranaki-daily-

news/opinion/9464080/Retiring-health-members-say-Maorineglected

Harris, R., Tobias, M., Jeffreys, M., Waldegrave, K., Karlsen, S., \& Nazroo, J. (2006). Māori health and inequalities in New Zealand: The impact of racism and deprivation. The Lancet 367, 2005-2009

Haslam, N. (2006). Dehumanization: An integrative review. Personality and Social Psychology Review, 10(3), 252-264.

Hirini, P. R., Flett, R. A., Kazantzis, N., Long, N. R., Millar, M. A., \& MacDonald, C. (1999). Health care needs for older Maori: A study of kaumatua and kuia. Retrieved from http://www.msd.govt.nz/documents/about-msd-and-ourwork/publications-resources/journals-and-magazines/socialpolicy-journal/spj13/13-health-care-older.doc

Jansen, P., Bacal, K., Crengle, S. (2009). He ritenga whakaaro: Māori experiences of health services. Retrieved from http://www.nzdoctor.co.nz/media/6399/He-RitengaWhakaaro.pdf

Jones, R. (2000). Traditional Maori healing. Pacific Health Dialogue, 7(1), 107-109. Retrieved from http:/ / www.pacifichealthdialog.org.fj/Volume\%207/No1\%20Maor i\%20Health\%20in\%20New\%20Zealand/Viewpoints\%20and\%20Pe rspectives/Traditional\%20Maori\%20healing.pdf

Ministry of Health (2009). He ritenga whakaaro: Māori experiences of health services. Retrieved from http://www.health.govt.nz/publication/he-ritenga-whakaaromaori-experiences-health-services

Ministry of Health (2011). Te Uru Kahikatea Maori work plan 20112017. Retrieved http://www.publichealthworkforce.org.nz/data/media/document s/Maori\%20PHWD/TUK\%20Maori\%20workplans/FINAL\%20NOV \%202011\%20Maori\%20public\%20health\%20action\%20plan03.pdf 
Nettleton, S. (2006). The sociology of health and illness. Cambridge, England: Polity Press.

Nursing Council of New Zealand. (2011). Guidelines for cultural Safety, the Treaty of Waitangi and Maori health in nursing education and practice. Retrieved from http://nursingcouncil.org.nz/content/download/721/2871/file/ Guidelines\%20for\%20cultural\%20safety,\%20the\%20Treaty\%20of \%20Waitangi,\%20and\%20Maori\%20health\%20in\%20nursing\%20 education $\% 20$ and $\% 20$ practice.pdf.

Penn, N. E., Kar, S., Kramer, J., Skinner, J. \& Zambrana, R. E. (1995). Ethnic minorities, health care systems, and behavior. Health Psychology, 14(7), 641-646.

Penney, L., Barnes, H. M., \& McCreanor, T. (2011). The blame game: Constructions of Mäori medical compliance. AlterNative: An international journal of indigenous peoples, 7(2), 73-86.

Pharmaceutical Management Agency (2013). Improving access and optimal use of medicines. Retrieved from http://www.pharmac.health.nz/assets/infosheet-improve-accessoptimal-use.pdf

Rumball-Smith, J., Sarfati, D., Hider, P., \& Blakely, T. (2013). Ethnic disparities in the quality of hospital care in New Zealand, as measured by 30-day rate of unplanned readmission/death. International Journal for Quality in Health Care, 25(3). doi:10.1093/intqhe/mzt012

Sachdev, P. (1990) Mental health and illness of the New Zealand Māori. Transcultural Psychiatric Research Review, 27(5):85-111.

Te Karu, L., Bryant, L., \& Elley, R. (2013). Maori experiences and perceptions of gout and its treatment: A kaupapa Maori qualitative study. Journal of Primary Health Care, 5(3), 214-222.

The Royal New Zealand College of General Practitioners (2007). Cultural competence: Advice for GPs to create and maintain culturally competent general practices in New Zealand. Retrieved from

http://www.rnzcgp.org.nz/assets/documents/Publications/Colle ge-Resources/Cultural-Competence.pdf

Thomas, D. R., Arlidge, B., Arroll, B., \& Elder, H. (2010). General practitioners' views about diagnosing and treating depression in Maori and non-Maori patients. Journal of Primary Health Care, 2(3), 208-216. 
Walker, T., Signal, L., Russell, M., Smiler, K. \& Tuhiwai-Ruru, R. (2008). The road we travel: Māori experience of cancer. The New Zealand Medical Journal, 121(1279), 27-35.

White, K. (2009). An introduction to the sociology of health \& illness (2nd ed.). London, England: Sage Publications Inc.

Willams, P. N., Gray, M. A., Ka'ai, T. M., Moorfield, J. C., Mcpherson, K. M., Weinstein, P., \& Nacey, J. N. (2003). Maori men's perceptions and experiences of health seeking for prostate health problems in New Zealand. Pacific Health Dialogue, 10(2), 71-78.

Wilson, D., \& Barton, P. (2012). Indigenous hospital experiences: A New Zealand case study. Journal of Clinical Nursing, 21(15), 23162326. doi:10.1111/j.1365-2702.2011.04042.x 